\section{Serum gastrin concentration in neonates with early-onset severe infections}

\author{
Stężenie gastryny w surowicy \\ u noworodków z wczesnymi ciężkimi \\ zakażeniami
}

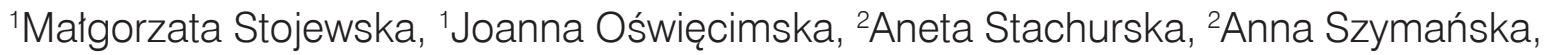 \\ ${ }^{2}$ Katarzyna Staśkiewicz, ${ }^{2} U r s z u l a ~ G o d u l a-S t u g l i k$
}

${ }^{1}$ Department and Clinic of Pediatrics in Zabrze, Medical University of Silesia, Katowice, ${ }^{2}$ Department and Clinic of Neonatal Intensive Care in Zabrze, Medical University of Silesia, Katowice

\section{Key words}

gastrin, full-term neonate, preterm neonate, earlyonset infection

\section{Abstract}

Introduction. Effect of early-onset infections on serum gastrin concentration in neonates is not well known. Aim. The evaluation of serum gastrin concentration in neonates with regards to their sex, fetal maturity, type of delivery, occurrence of early-onset infections, birth asphyxia and gastrointestinal disorders. Material and methods. In 97 (54 full-term, 43 preterm) neonates, among them 54 infected and 43 healthy ones, twice serum gastrin concentration by radioimmunoassay was measured. Results. Infected full-term neonates in the first week of life had significantly higher gastrin concentration than infected preterm neonates and healthy full-term. In the third week of life, infected preterm neonates had higher mean gastrin value than healthy preterm and infected full-term neonates. Significant lower mean gastrin concentration was noted in infected full-term neonates with gastrointestinal disorders than in infected neonates without these signs. Prematurity and presence of early-onset infection in neonates were independent predictors of gastrin values in both measurements. Conclusions. 1. Differences in serum gastrin concentrations between full-term and preterm neonates may depend on early-onset severe infections connected with intensive therapy, on gastrointestinal tract maturity and functional disorders and type of nutrition. 2. Higher gastrin concentrations in infected full-term
'Katedra i Klinika Pediatrii w Zabrzu, Ślaski Uniwersytet Medyczny, Katowice, ${ }^{2}$ Katedra i Klinika Intensywnej Terapii i Patologii Noworodka w Zabrzu, Śląski Uniwersytet Medyczny, Katowice

\section{Słowa kluczowe}

gastryna, noworodek donoszony, noworodek urodzony przedwcześnie, wczesne zakażenie

\section{Streszczenie}

Wstęp. Wpływ wczesnych zakażeń na stężenie gastryny u noworodków nie został dobrze poznany. Cel. Ocena stężeń gastryny w surowicy u noworodków z uwzględnieniem ich płci, dojrzałości ciążowej, sposobu urodzenia, wystąpienia wczesnego zakażenia, niedotlenienia i zaburzeń przewodu pokarmowego. Materiał i metody. U 97 (54 donoszonych, 43 urodzonych przedwcześnie) noworodków, w tym u 54 z zakażeniami i 43 zdrowych, oznaczono dwukrotnie metodą radioimmunologiczną stężenie gastryny. Wyniki. W pierwszym tygodniu życia noworodki donoszone z zakażeniem miały istotnie statystycznie wyższe wartości gastryny niż zdrowe i urodzone przedwcześnie z zakażeniem. W trzecim tygodniu życia wcześniaki z zakażeniem miały istotnie wyższe wartości gastryny niż zdrowe i wyższe niż chore noworodki donoszone. Wykazano niższe stężenia gastryny u noworodków donoszonych z zakażeniem i zaburzeniami przewodu pokarmowego niż u noworodków z zakażeniem bez tych objawów. Wcześniactwo i wczesne zakażenia okazały się niezależnymi czynnikami predykcyjnymi stężeń gastryny w obu pomiarach. Wnioski. 1. Różnice w stężeniu gastryny w surowicy między noworodkami donoszonymi i urodzonymi przedwcześnie mogą zależeć od wystąpienie wczesnych ciężkich zakażeń wymagających intensywnej terapii, od dojrzałości i zaburzeń czynnościowych przewodu pokarmowego 
than in healthy neonates may proof stimulation gastrointestinal tract to gastrin secretion in response to infection. 3. Lower gastrin concentrations in infected preterm than in healthy and in infected full-term neonates may suggest their decrease ability to gastrin secretion in the first week of life. 4. Significantly increase gastrin concentration in the third week may be connected with better neonatal health, full enteral nutrition independently of infection in the past, birth asphyxia and neonatal sex.

Pediatr. Endocrinol. 2017.16.2.59.101-108.

(C) Copyright by PTEiDD 2016 oraz rodzaju żywienia. 2. Wyższe stężenia gastryny u noworodków chorych na zakażenia niż u zdrowych mogą potwierdzać stymulację wydzielania gastryny przez przewód pokarmowy w odpowiedzi na zakażenie. 3. Obniżone stężenia gastryny u noworodków urodzonych przedwcześnie z zakażeniem niż u zdrowych i chorych noworodków donoszonych sugeruje ich obniżoną zdolność do wydzielania gastryny w pierwszym tygodniu życia. 4. Istotny wzrost stężenia gastryny w trzecim tygodniu życia może wynikać z lepszego stanu zdrowia, żywienia enteralnego, niezależnie od przebytego zakażenia, niedotlenienia okołoporodowego i płci noworodka.

Endokrynol. Ped. 2017.16.2.59.101-108.

(C) Copyright by PTEiDD 2016

preterm neonates and to assess the relationship between their gestational age, birth weight, birth asphyxia, mode of nutrition, type of delivery and occurrence of severe early-onset infection complicated by gastrointestinal disorders. Tracy [2], is a gut hormone secreted mainly by G cells in the mucous membrane of antroduodenal region of the stomach from where it is released to blood [3]. Small amounts are synthetized further down the intestinal tract, in the fetal pancreas, in a few cerebral and peripheral neurons, in the pituitary gland and in spermatozoa. The main physiological role of gastrin is stimulation of cellular proliferation and differentiation of the mucous membrane of the digestive tract, regulation of hydrochloric and pepsin secretion, water and electrolyte secretion to pancreatic juice and bile, inducing tonic spasm of the lower esophageal sphincter and increasing blood flow in mucous membrane of the stomach $[4,5]$.

Gastrin exerts immunomodulatory and proinflammatory effects. It plays a role of transcriptional activator, that targets promoter regions of cytokines, chemokines and other proinflammatory mediators [4]. Gastrin does not cross placenta, and its concentrations in blood depend on neonatal synthesis and gestational age [6]. Its concentration in cord blood (40-80 $\mathrm{pg} / \mathrm{ml}$ ) is higher than in mother during delivery and significantly increases within first six days of life [6,7]. Serum gastrin concentration (sgc) in neonates are influenced by phototherapy, perinatal asphyxia or necrotizing enterocolitis $[8,9]$.

The relationship between sgc and neonatal infections is not well known yet $[9,10]$. The aim of our study was to evaluate the sgc in full-term and

\section{Material}

The study population comprised 97 neonates (56 female and 41 male; 54 full-term and 43 preterm) aged from 3 to 5 days of life, with birth weight $>1250 \mathrm{~g}$, including 54 infected and 43 healthy (control group). All the neonates eligible for inclusion in the study had no congenital anomalies, other genetic disorders, small for gestational age, hyperbilirubinemia or gestational age $<32$ and $>42$ week.

They were divided into 4 groups: group I - 30 infected full-term; II group - 24 infected preterm; I); group IV - 19 healthy preterm (control for group II). All infected neonates were treated in the NICU in Zabrze within 2008 - 13 years. Healthy neonates were delivered in Obstetric Department in Zabrze in the same time.

Clinical characteristics of the study population are shown in table I.

Early-onset (diagnosed $<121$ hours of life) infections involved sepsis (29 cases: 19 in group I and 10 in group II) and bilateral pneumonia (11 and 14 neonates, respectively). The septic neonates fulfilled three of the diagnostic criteria: 1) positive blood cultures (gram negative - 17, among them E.coli - 6, Klebsiella pneumonia - 6,

Serum gastrin concentration in neonates with early-onset severe infections group III - 24 healthy full-term (control for group 
Table I. Clinical characteristics of all 97 examinated neonates

Tabela I. Kliniczna charakterystyka wszystkich 97 badanych noworodków

\begin{tabular}{|c|c|c|c|c|c|c|c|}
\hline \multirow{2}{*}{ 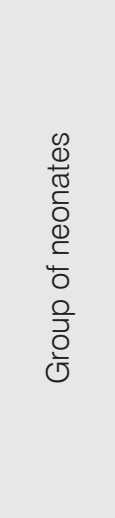 } & \multirow{2}{*}{ 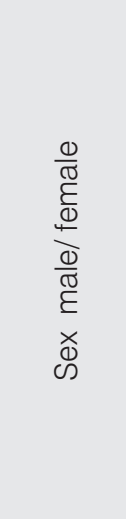 } & \multirow{2}{*}{ 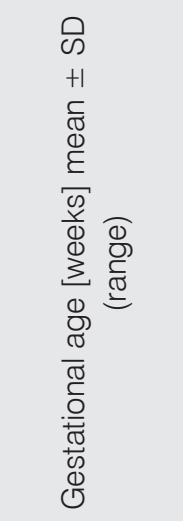 } & \multirow{2}{*}{ 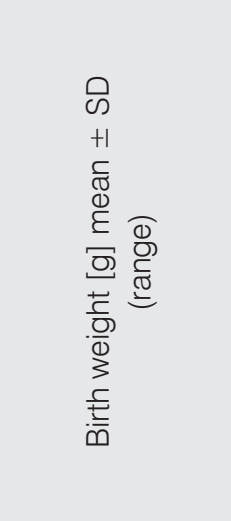 } & \multirow{2}{*}{ 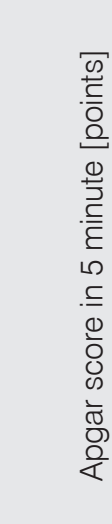 } & \multirow{2}{*}{ ᄃ } & \multicolumn{2}{|c|}{$\begin{array}{l}\frac{2}{0} \\
\frac{2}{2} \\
\frac{2}{0} \\
0 \\
\frac{0}{0} \\
0 \\
0 \\
0\end{array}$} \\
\hline & & & & & & 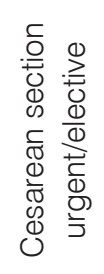 & 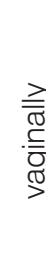 \\
\hline $\begin{array}{c}I \\
N=30\end{array}$ & $\begin{array}{l}m=11 \\
f=19\end{array}$ & $\begin{array}{c}39.6 \pm 0.93 \\
(38.0-42.0)\end{array}$ & $\begin{array}{c}3412.2 \pm 350.8 \\
(2800-4200)\end{array}$ & $\begin{array}{c}\leq 3 \\
4-7 \\
8-10\end{array}$ & $\begin{array}{c}1 \\
14 \\
25\end{array}$ & $3 / 2$ & 25 \\
\hline $\begin{array}{c}\| \\
N=24\end{array}$ & $\begin{array}{l}m=10 \\
f=14\end{array}$ & $\begin{array}{l}35.1 \pm 3.2 \\
(32.0-37.0)\end{array}$ & $\begin{array}{c}1838.2 \pm 242.3 \\
(1300-2450)\end{array}$ & $\begin{array}{c}\leq 3 \\
4-7 \\
8-10\end{array}$ & $\begin{array}{c}2 \\
3 \\
19\end{array}$ & $12 / 2$ & 10 \\
\hline $\begin{array}{c}\text { III } \\
N=24\end{array}$ & $\begin{array}{l}m=11 \\
f=13\end{array}$ & $\begin{array}{c}39.9 \pm 0.96 \\
(38.0-42.0)\end{array}$ & $\begin{array}{c}3300.8 \pm 287.2 \\
(2900-4150)\end{array}$ & $\begin{array}{c}\leq 8 \\
9-10\end{array}$ & $\begin{array}{c}0 \\
24\end{array}$ & $0 / 2$ & 22 \\
\hline $\begin{array}{c}\text { IV } \\
N=19\end{array}$ & $\begin{array}{l}m=9 \\
f=10\end{array}$ & $\begin{array}{l}35.5 \pm 2.5 \\
(32.0-37.0)\end{array}$ & $\begin{array}{c}2030.4 \pm 247.5 \\
(1750-2500)\end{array}$ & $\begin{array}{c}\leq 8 \\
9-10\end{array}$ & $\begin{array}{c}3 \\
16\end{array}$ & $0 / 2$ & 17 \\
\hline
\end{tabular}

Klebsiella oxytoca - 3, Pseudomonas aeruginosa - 2; gram positive: Staphylococcus aureus 4, Streptococcus group B - 3; Staphylococcus haemolyticus and epidermidis MR species - 5 cases), 2) inflammatory signs in two organs, mainly pneumonia, purulent meningitis and urinary tract infection, c) biochemical/haematological disorders as metabolic acidosis, hypo- $(<3,4 \mathrm{mmol} / \mathrm{l})$ or hyperglycemia $(>7,8 \mathrm{mmol} / \mathrm{l})$, thrombocytopenia $(<100,0 \mathrm{G} / \mathrm{l})$, anaemia $(\mathrm{Ht}<35 \%)$, leucocytosis $>30,0 \mathrm{G} / \mathrm{l}$ or leukopenia $<4,0 \mathrm{G} / \mathrm{L}$, increase of C-reactive protein and D-dimers concentrations.

All the 25 neonates with isolated pneumonia, confirmed by X-ray examinations, presented respiratory distress: tachypnea, grunting, dyspnea and cyanosis within 48 first hours of life. Pulmonary hypertension was diagnosed in two pneumonic full-term neonates. Neutrophils in endotracheal aspirates were noted in 14 orotracheally intubated and mechanically ventilated neonates with pneumonia on the first day of hospitalization, but cultures were negative.
In 30 (56\%) infected neonates (11 from group I and 19 from group II), as clinical signs of infections, such gastrointestinal disorders, as meteorismus, vomiting, gastroenterostasis, constipation and feeding intolerance, were noted.

All infected neonates were treated with broad spectrum antibiotics, mainly aminoglycosides (netilmycin or amikacin) with ampicillin. It was necessary to administer vancomycin in all cases of staphylococcal sepsis due to MR strains. In 27 (50\%) - 14 with pneumonia and 13 with sepsis neonates - mechanical ventilation from the first day of life, in 6 (11\%) n-CPAP, in $30(56 \%)$ total parenteral nutrition, in 25 (46\%) catecholamines, in $8(15 \%)$ concentrated erythrocytes, in $5(9 \%)$ concentrated platelets and in 2 (4\%) filgrastin were applied.

In 12 (30\%) severe infected full-term (8 septic and 4 with pneumonia) and 18 (75\%) preterm neonates (9 septic and 9 with pneumonia) total parenteral nutrition in the first 5 days of life was necessary. In the first week of life 10 (33\%) infected 
full-term and 4 (17\%) preterm neonates obtained partial parenteral nutrition (without lipids) and partial enteral nutrition (starting from minimal feeding with mother's milk). In the 8 infected fullterm neonates breast milk were applied from the birth. Five sick preterm neonates from birth till $18^{\text {th }}$ day of life received total parenteral nutrition, because of necrotizing enterocolitis ( 3 cases) and meteorismus with feeding intolerance ( 2 cases). In the third week of life all infected full-term and 14 preterm neonates were enterally fed and 6 infected preterm neonates obtained partial parenteral and enteral nutrition.

In the third week of life the general healthy state of all 19 full-term and 5 preterm septic neonates was good, without hematological and biochemical disorders with negative blood and urine cultures. In 5 preterm septic neonates mild respiratory disorders (apnoeic attacs), meteorismus, feeding intolerance, hiperbilirubinemia and increased C-reactive protein were noted. Two full-term and 6 preterm neonates with congenital pneumonia were in good healthy state, but presented little inflammatory pulmonary changes confirmed by $\mathrm{X}$-ray in the third week of life. Others pneumonic neonates were recovered without complication.

\section{Control subjects}

The control groups included 24 full-term and 19 preterm neonates, 23 girls and 20 boys, born vaginally by healthy, non-smoking mothers, with an Apgar score $>8$ points, breast fed from birth, without signs of infection and adaptation disorders.

\section{Methods}

\section{Collection of blood samples and serum gastrin measurement}

In all neonates $1 \mathrm{ml}$ of peripheral venous blood were collected twice: between $3 \mathrm{rd}$ and 5 th day of life and in the third week of life, between $7.30-8.00^{\mathrm{AM}}$, always two hours postprandial, both in breast-fed healthy and breast-fed or formula-fed infected infants, centrifuged and stored in $-22^{\circ} \mathrm{C}$ until measured. SGC was determined using commercial RIA test kits (KGAD1, DPA, Los Angeles, USA). The antibody binds to carboxyl-terminal bioactive site of sulfated and nonsulfated gastrins, and binds gastrin-17 and gastrin-34 with equal affinity. The detection limit of the assay was $4.5 \mathrm{pg} / \mathrm{ml}$. The intra- and interassay variations were 6.3 and $5.2 \%$, respectively. None of the study neonates received blood or hematogenous preparation transfusion beforehand.

The study was approved by the Bioethics Commission of Medical University of Silesia (NN 013/44/I/01). A written consent was obtained from the parents of all participating neonates.

\section{Clinical methods}

Clinical data of the neonates were collected from case reports. Fetal maturity was assessed by new Ballard score [11]. Birth asphyxia according to low Apgar score ( $<5$ points) at the 5 minute of life, $\mathrm{pH}$ of venous blood $<7,10$, decrease $\mathrm{BE}<-10$ and increase of lactates concentration $>2,5 \mathrm{mmol} / \mathrm{l}$ in the first hour of the life was diagnosed. Diagnosis of early-onset sepsis and pneumonia was stated on widely known criteria [12,13].

\section{Statistical analysis}

All statistical tests were performed using STATISTICA 10,0; StatSoft Inc. and Tulsa, 2011. Distribution of data was tested with Kolmogorov - Smirnov test. Values were expressed as mean \pm SD (standard deviation) for continuous variable with normal distribution. Comparisions between groups were performed using ANOVA with posthoc Tukey's test and non-parametric Friedman's ANOVA test. Spearman linear correlation for continous parameters (gestational age, birth weight) and logit regression for dichotomic parameters (sex, prematurity, occurrence of infection) were performed. Multiple backwards step-wise regression model was used to determine independent factors influencing sgc. A $p$-value below 0,05 was inferred significant.

\section{Results}

The sgc in infected full-term neonates in the first week of life $(29,4 \pm 9,4$; range $11,9-40,3 \mathrm{pg} /$ $\mathrm{ml})$ was statistically significant $(\mathrm{p}<0,0001)$ higher than in healthy full-term neonates $(14,7 \pm 3,1$; range $11,3-19,96 \mathrm{pg} / \mathrm{ml})$ and than $(\mathrm{p}<0,001)$ in infected preterm neonates $(15,7 \pm 3,5$; range $11,5-$ $21,3 \mathrm{pg} / \mathrm{ml}$ ). In infected preterm neonates sgc was lower $(\mathrm{p}<0,03)$ than in healthy $(20,3 \pm 13,9 \mathrm{pg} / \mathrm{ml})$. Significant difference $(p<0,03)$ in sgc between healthy full-term and preterm neonates was noted in first week of life - Fig. 1.

In the third week of life, sgc in all study groups was significantly higher in comparison to the first examination. The infected preterm neonates

Serum gastrin concentration in neonates with early-onset severe infections 


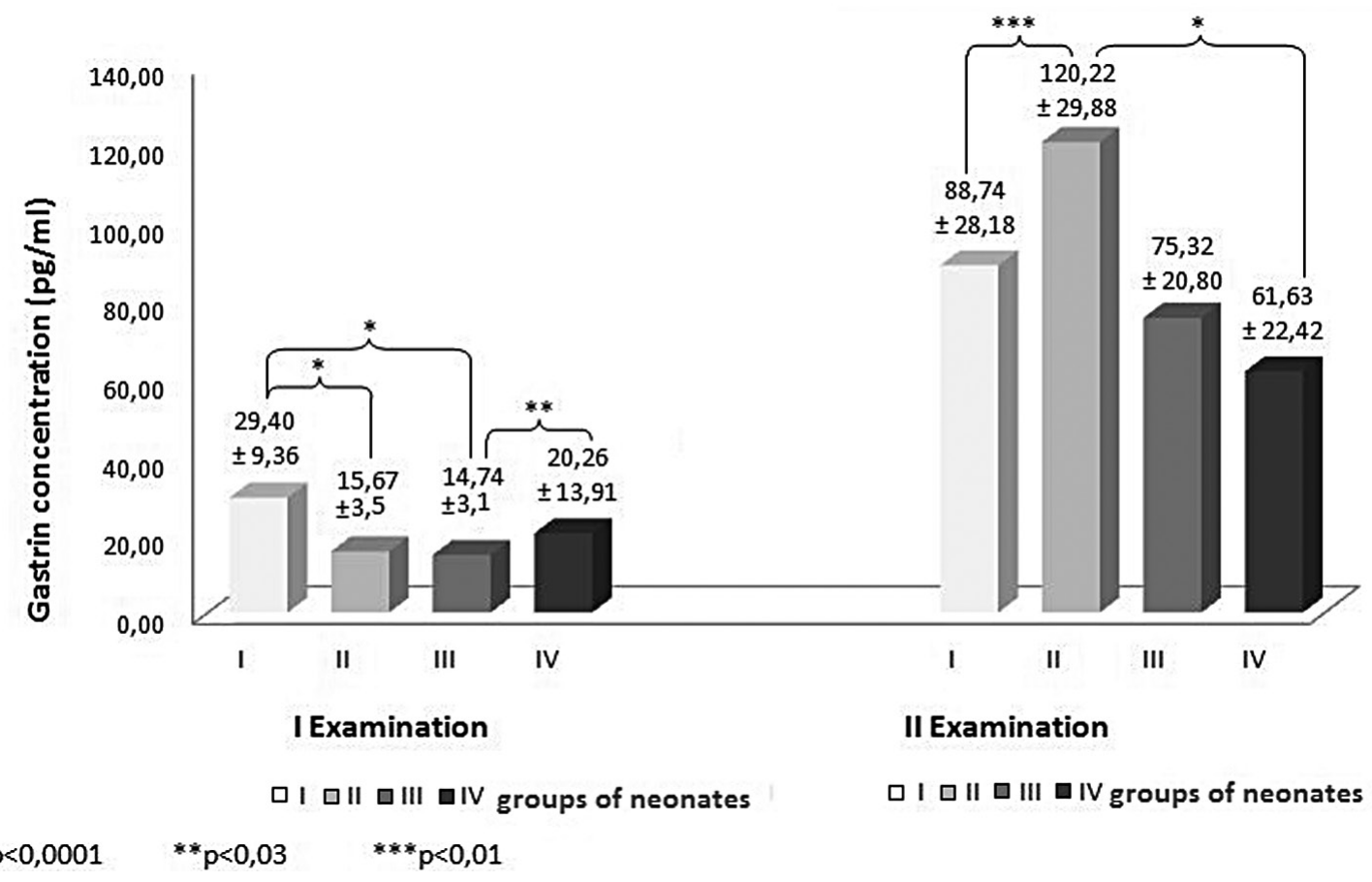

Fig. 1. Serum gastrin concentration in examined groups of neonates

Ryc. 1. Stężenie gastryny w surowicy w czterech grupach badanych noworodków

had statistically significant $(\mathrm{p}<0,001)$ higher $\mathrm{sgc}$ than the healthy ones $(120,2 \pm 29.9$; range $87,8-$ 167,7 and $61,6 \pm 22,4$; range $45,8-113,4 \mathrm{pg} / \mathrm{ml}$, respectively) and higher $(\mathrm{p}<0,01)$ than infected full-term babies $(88,7 \pm 28,2$; range $35,9-138,5 \mathrm{pg} /$ $\mathrm{ml})$. In enteral fed infected full-term neonates sgc was higher than in healthy, but without statistical significance - Fig. 1 .

The sgc in the first week of life in the infected preterm neonates with gastrointestinal disorders $(21,1 \pm 9,3 \mathrm{pg} / \mathrm{ml})$ was significantly $(\mathrm{p}<0,001)$ higher than in the preterm infants without such problems $(11,9 \pm 0.6 \mathrm{pg} / \mathrm{ml})$. In the infected fullterm neonates with gastrointestinal disorders the mean sgc $(79,1 \pm 22,4 \mathrm{pg} / \mathrm{ml})$ was significantly $(p<0,01)$ lower than in full-term neonates whithout these symptoms $(114.7 \pm 31.6 \mathrm{pg} / \mathrm{ml})$.

In the third week of life, the mean sgc in the infected full-term neonates with gastrointestinal disorders, including necrotizing enterocolitis, $(78,9 \pm 27,6$; range $35,9-105,1 \mathrm{pg} / \mathrm{ml})$ and in preterm neonates (127.1 \pm 35.3 ; range $88,8-167,7$ $\mathrm{pg} / \mathrm{ml})$ did not differ significantly $(\mathrm{p}>0,05)$ from the mean value in the infected neonates without these disturbances. We observed no statistically significant $(p>0,05)$ differences in mean sgc between male and female infected and healthy term and preterm neonates, between pneumonic and septic, asphyxiated and nonasphyxiated infected neonates. Table II presented comparison sgc in the first examination between infected fullterm and preterm neonates, according to the mode of nutrition. Any significant differences $(p>0,05)$ in sgc in first examination between enteral and parenteral fed full-term and preterm neonates was noted. In full-term neonates, obtaining full enteral nutrition and total parenteral nutrition, sgc was statistically significant higher than in infected preterm neonates (tab. II). In the third week of life statistically significant higher sgc in 14 enteral fed infected preterm $(120,21 \pm 29,9 \mathrm{pg} / \mathrm{ml})$ than in breast fed full-term neonates $(87,2 \pm 27,3)$ was noted. In 5 preterm neonates with total parenteral nutrition in third week of life sgc was $96,3 \pm 46,2 \mathrm{pg} /$ $\mathrm{ml}$, but in 6 preterm babies, who obtained partial enteral nutrition and partial breast milk sgc was only mild higher $-108,79 \pm 34,26 \mathrm{pg} / \mathrm{ml}(\mathrm{p}>0,05)$.

Table III summarizes correlations between sgc and clinical parameters in the first and third week of life in all the study neonates. In both measurements, sgc significantly correlates with gestational age, prematurity and presence of early- 
Table II. Serum gastrin concentrations $[\mathrm{pg} / \mathrm{ml}]$ in the first examination in infectious neonates, according to the kind of nutrition

Tabela II. Stężenie gastryny w surowicy (pg/ml) w pierwszym badaniu u noworodków z zakażeniem z uwzględnieniem rodzaju żywienia

\begin{tabular}{|c|c|c|c|c|c|c|}
\hline \multirow{2}{*}{ Kind of nutrition } & \multicolumn{2}{|c|}{$\begin{array}{l}\text { Full term neonates } \\
\qquad n=30\end{array}$} & \multirow{2}{*}{ Kind of nutrition } & \multicolumn{2}{|c|}{ Preterm neonates $n=24$} & \multirow{2}{*}{$p$} \\
\hline & mean & $\pm \mathrm{SD}$ & & mean & $\pm \mathrm{SD}$ & \\
\hline Breastmilk & 30,26 & 12,32 & $\begin{array}{l}\text { Breastmilk } \\
\quad n=2\end{array}$ & 15,08 & 2,73 & $<0,01$ \\
\hline $\begin{array}{c}\text { Total } \\
\text { parenteralnutrition }\end{array}$ & 36,12 & 6,82 & $\begin{array}{c}\text { Total } \\
\text { parenteralnutrition } \\
n=18\end{array}$ & 18,61 & 4,96 & $<0,05$ \\
\hline $\begin{array}{c}\text { Parenteralnutrition + } \\
\text { Breastmilk }\end{array}$ & 28,02 & 7,87 & $\begin{array}{c}\text { Parenteral nutrition } \\
+ \text { Breast milk } \\
n=4\end{array}$ & 20,21 & 17,92 & $>0,05$ \\
\hline$p$ & \multicolumn{2}{|c|}{$>0,05$} & \multicolumn{4}{|c|}{$>0,05$} \\
\hline
\end{tabular}

Table III. Correlations between serum gastrin concentration and clinical parameters in the study neonates Tabela III. Korelacja między stężeniem gastryny w surowicy, a klinicznymi parametrami badanych noworodków

\begin{tabular}{|c|c|c|c|c|}
\hline \multirow{3}{*}{ Parameters } & \multicolumn{4}{|c|}{ Serum gastrin concentration } \\
\hline & \multicolumn{2}{|c|}{$r^{a}\left(c^{2} i^{b}\right)$} & \multicolumn{2}{|c|}{$\mathrm{R}^{c}$} \\
\hline & first week of life & third week of life & first week of life & third week of life \\
\hline Gestational age [weeks] & $\begin{array}{c}0.30 \\
p=0.003\end{array}$ & $\begin{array}{c}-0.18 \\
p=0.08\end{array}$ & $\begin{array}{c}-0.01 \\
p=0.99\end{array}$ & $\begin{array}{c}0.01 \\
p=0.95\end{array}$ \\
\hline Birth weight $[\mathrm{g}]$ & $\begin{array}{c}0.31 \\
p=0.002\end{array}$ & $\begin{array}{c}-0.14 \\
p=0.165\end{array}$ & $\begin{array}{c}-0.02 \\
p=0.86\end{array}$ & $\begin{array}{c}0.20 \\
p=0.06\end{array}$ \\
\hline Sex & $\begin{array}{c}0.85 \\
p=0.35\end{array}$ & $\begin{array}{c}0.02 \\
p=0.89\end{array}$ & $\begin{array}{c}0.13 \\
p=0.21\end{array}$ & $\begin{array}{c}0.02 \\
p=0.80\end{array}$ \\
\hline $\begin{array}{l}\text { Prematurity (neonates born } \\
\leq 37 \text { weeks of gestation) }\end{array}$ & $\begin{array}{c}12.14 \\
p<0.001\end{array}$ & $\begin{array}{c}4.03 \\
p=0.04\end{array}$ & $\begin{array}{c}-0.37 \\
p=0.001\end{array}$ & $\begin{array}{c}0.22 \\
p=0.03\end{array}$ \\
\hline Presence of infection & $\begin{array}{c}17.73 \\
p<0.001\end{array}$ & $\begin{array}{c}29.75 \\
p<0.001\end{array}$ & $\begin{array}{c}0.43 \\
p<0.01\end{array}$ & $\begin{array}{c}0.58 \\
p<0.001\end{array}$ \\
\hline Gastrin at first week of life & - & $\begin{array}{c}0,01 \\
p=9.09\end{array}$ & - & $\begin{array}{c}-0.30 \\
p=0.003\end{array}$ \\
\hline
\end{tabular}

a Spearman linear correlation for continuous parameters ${ }^{\mathrm{b}}$ Logit regression for dichotomy parameters ${ }^{\mathrm{c}}$ Partial correlation for the multiple regression model 
onset infection. The association between sgc and birth weight was present only in the first week of age. Multiple regression analysis confirmed the role of prematurity and the presence of infection as independent predictors of sgc.

\section{Discussion}

In our study, mean sgc in infected full-term neonates was significantly higher than in infected preterm and healthy full-term neonates, but infected preterm neonates presented delayed reactions with the lowest sgc in the first week of life, but the highest in the third week. Prematurity and presence of infection were independent predictors of SGC for both measurements. We support, that elevated sgc in neonates may be an indicator of the maturity of immunological response of gastrointestinal tract to early-onset infection.

The first evidence of a relationship between gastrin and immune system was reported by Okahata et al. [14], who demonstrated gastrin immunoreactivity in pure populations of polymorphonuclear leukocytes and mononuclear cells from human peripheral blood. Gastrin is a negative modulator of the phagocytosis by human neutrophils, suppresses their apoptosis and increases chemotaxis [15].

Gastrin is able to modulate lymphocyte proliferation and activity, but the results are conflicting. Gastrin increases the secretion of interleukin-2 and stimulates cell growth in resting peripheral blood lymphocytes and lymphocytic cell lines [16, 17]. Increases of the proinflammatory molecules expression, mainly IL-8 and the enzyme COX-2, in gastric epithelial cells transfected with CCK2R [18].

In our study neonatal infections with gastrointestinal disorders had a significant impact on decrease of sgc only in the first week of life in full-term neonates, while the opposite relationship was observed in infected preterm infants. This suggests different sgc regulation in our patients. This may result from immaturity of gastrointestinal tract and disturbances in the regulation of gastrin production by somatostatin or cholecystokinin $[19,20]$.
A critical role of toll like receptor 4 (TLR4) for bacterial lipopolysaccharide in the pathogenesis of gastrointestinal diseases has been indentified [21]. These receptors modulate the migration of neutrophils to infectious foci, favoring bacteremia and mortality. Gastrin releasing peptide (GRP) that elicits gastrin release is elevated in systemic inflammatory response syndrome associated. Petronilho et al. [22] proved the beneficial action of GRP receptor antagonists administration in controlling the inflammatory response in sepsis through a mechanism involving at least inhibition of TLR-4 signaling. Therefore, increased sgc in infected preterm neonates with gastrointestinal disorders may result from increased GRP levels. Futher studies are warrant to verify in large group of infected infants below one month of age, because gut hormones play an important role in the adaptation of the immature neonatal gut and their production is modulate by a lot of risk factors connected with infection. New studies on gastrin and motilin secretion in preterm neonates (in which sepsis and necrotizing enterocolitis were noted), following prebiotics supplementation indicate, that a prebiotics enriched formula had any effect on sgc [23].

\section{Conclusions}

1. Differences in serum gastrin concentrations between full-term and preterm neonates may depend on early-onset severe infections connected with intensive therapy, on gastrointestinal tract maturity and functional disorders and kind of nutrition. 2. Higher gastrin concentrations in infected full-term than in healthy neonates may proof stimulation gastrointestinal tract to gastrin secretion in response to infection. 3. Lower gastrin concentrations in infected preterm than in healthy and in infected full-term neonates may suggest their decrease ability to gastrin secretion in the first week of life. 4. Significantly increase of gastrin concentration in the third week may be connected with better neonatal health, full enteral nutrition, independently of infection in the past, birth asphyxia and neonatal sex. 


\section{References / Piśmiennictwo}

1. Edkins J.S.: On the chemical mechanism of gastric secretion. Proc. R. Soc. Lond. B Biol. Sci, 1905:76, 376.

2. Gregory R.A., Tracy H.J.: The constitution and properties of two gastrins extracted from dog antral mucosa. Gut, 1964:5, 103-110.

3. Carvajal S.H., Mulvihill S.J.: Intestinal peptides and their relevance in pediatric disease. Semin. Pediatr. Surg., 1995:4, 9-21.

4. Calatayud S., Alvares A., Victor V.M.: Gastrin: An Acid-Releasing, Proliferative and Immunomodulatory Peptide? 2010:10, 8-19.

5. Koh T.J., Chen D.: Gastrin as a growth factor in the gastrointestinal tract. Regul. Pept., 2000:93, 37-44.

6. Euler A.R., Byrne W.J., Cousins L.M., Ament M.E. et al.: Increased serum gastrin concentrations and gastric acid hyposecretion in the immediate newborn period. Gastroenterology, 1997:72, 1271-1217.

7. Lucas A., Bloom S.R., Aynsley-Green A.: Gastrointestinal peptides and the adaptation to extrauterine nutrition. Can. J. Physiol. Pharmacol., 1985:63, 527-537.

8. Gounaris A., Alexiou N., Costalos C., Daniilidou M. et al.: Gut hormone levels in neonates under phothotherapy. Early Hum. Dev., 1988:51, 57-60.

9. Gounaris A., Alexiou N., Costalos C., Daniilodou M. et al.: Gut hormone concentrations in preterm infants with necrotizing enterocolitis. Acta Pediatr. 1997:7, 762-763.
10. Bacchini P.L., Romanini E., Magnani C. et al.: Apparent life threatening event and gastric antral ulcer in a full-term infant: any possible relationship? Acta Biomed., 2010:81(2), 144- 146.

11. Ballard J.L., Khoury J.C., Wedig K., Wang L. et al.: New Ballard Score, expanded to include extremely premature infants. J. Pediatr., 1991:119, 417-423.

12. Maldanado Y.A., Nizet V., Klein J.O. et al.: Current concepts of infections of fetus and newborn infants. In: Infectious diseases of the fetus and newborn infants. Remington J.S., Klein J.O. (ed). Saunders Co. Elsevier, Philadelphia 2016, 3-23.

13. Szczapa J., Szczapa T.: Choroby układu oddechowego. W: Neonatologia. red J. Szczapa, PZWL Warszawa, 2015, 139-150.

14. Okahata H., Nishi Y., Muraki K., Sumii K. et al.: Gastrin/cholecystokine-like immunoreactivity in human blood cells. Life Sci., 1985:36, 369-733.

15. Abdalla E.E.: Modulation of human neutrophil apoptosis by gut hormones. Int. J. Health Sci. (Qassim), 2010:4(1), 53-58.

16. Carrasco M., Hernanz A., Dela Fuente M.: Effect of cholecystokin and gastrin on human peripheral blood lymphocyte functions, implication of cyclic AMP and interleukin 2. Regul. Pept., 1997:70, 135-142.

17. Iwata N., Murayama T., Matsumori Y. et al.: Autocrine loop through cholecystokine-B/gastrin receptors involved in growth of human leukemia cells. Blood, 1996:88, 2683-2686.

18. Subramaniam D., Ramalingam S., May R. et al.: Gastrin-mediated interleukin-8 and cyclooxygenase-2 gene expression: differential transcriptional and posttranscriptional mechanism. Gastroenterology, 2008:134, 10701082.

19. Li Z.L., Ye H.M., Wang J.S. et al.: Serum gastrin levels and clinical conditions in response to early minimal feeding in premature infants. Chin. J. Pediatr. 2008:46(4), 243-246.

20. Marchini G., Lagercrantz H., Milerad J. et al.: Plasma levels of somatostatin and gastrin in sick infants and small for gestational age infants. J. Pediatr. Gastroenterol. Nutr., 1988:7(5), 641644

21. Afrazi A., Branca M.F., Sodhi C.P.: Tolllike receptor 4-mediated endoplasmic reticulum stress in intestinal crypts induces necrotizing enterocolitis. J. Biol. Chem., 2014:289(14), 9584-9599.

22. Petronilho F., Vuolo F., Galant L.S. et al.: Gastrin-releasing peptide receptor antagonism induces protection from lethal sepsis: involvement of tolllike receptor 4 signaling. Mol. Med. 2012:18, 1209-1219.

23. Dasopoulou M., Briana D.D., Boutsikou T. et al.: Motilin and gastrin secretion and lipid profile in preterm neonates following prebiotics supplementation: a double-blind randomized controlled study. JPEN J. Parenter. Enteral. Nutr., 2015:39, 359-368. 